\title{
Légi szuverenitás és légi ellenőrző szolgálat a HORTHY-korszakban
}

A légi forgalom szabályozásáról szóló 1919-es párizsi egyezmény elismerte a légtér feletti nemzeti szuverenitást. A légi járművek esetében azonban, a tengeri közlekedés szabályaihoz hasonlóan, kimondta a békés áthaladás szabadságát, a polgári repülő eszközök esetében a közlekedés biztonságát szolgáló általános szabályok, katonai légi jármüvek esetében pedig az egyes államok légi felségjoga érvényesítéséből fakadó külön rendelkezések alapján. ${ }^{1}$

Az I. világháborút követő években Magyarország csak korlátozott légi szuverenitással rendelkezett. Az 1920. VI. 4-én aláirt és 1921. VII. 26-án érvénybe lépő trianoni békeszerződés mindössze 35000 főnyi hivatásos haderőt engedélyezett, repülő csapatokat és légvédelmi tüzérséget az ország nem tarthatott. A légierő állományát 2 hónapon belül le kellett szerelni, a katonai repülőanyagot pedig át kellett adnia a SZKEB* légügyi szerveinek. Magyarország 6 hónapig sem katonai, sem polgári repülőgépet nem építhetett, és nem hozhatott be külföldröl. A meglévő gépek számára 6 hónapra teljes repülési tilalmat rendeltek el, miközben a Szövetséges és Társult Hatalmak repülögépei a magyar légtérben szabadon közlekedhettek, és bármelyik repülőtéren leszállhattak. A Nagykövetek Tanácsa az 1922. I. 26-án lejáró repülési és repülöépítési tilalmat minden különösebb indok nélkül újabb fél évre meghosszabbította. ${ }^{2}$

A rendelkezések katonailag teljesen kiszolgáltatottá tették az országot, mert repülő erők és légvédelmi tüzérség nélkül a magyar állam nem érvényesíthette légi felségjogát, egy konfliktus esetén pedig nem tudta volna megvédelmezni a légterét. A helyzetet súlyosbította, hogy Magyarország ipari és közlekedési gócpontjainak többsége, a legfontosabb 10 település alig 20-40 km-re feküdt az új határoktól, ami csak 5-10 percnyi repülőutat jelentett. Budapestre a csehszlovák légierő 8-10 perc alatt lecsaphatott. Az ország területét az ellenséges gépek észak-déli irányban 40 perc, kelet-nyugati irányban 80 perc alatt átrepülhették. ${ }^{3}$

A magyar katonai vezetés igyekezett rejtett módon fenntartani egy minimális légierőt. A MAEFORT* keretei között, — polgári szervezetnek álcázva — felállítottak egy repülőcsoportparancsnokságot, melynek alárendeltségébe 1921 májusában egy vadászrepülő és egy felderítő század, egy kiképző keretszázad, valamint anyagszertár és javítóműhely tartozott. 1921. VIII. 1-jén a rejtés feltételeinek javítása érdekében a KEM* felállították a XI. (légiforgalmi) szakosztályt, amely a polgári légügyek intézése mellett a titkos légierő törzsének is helyet adott. ${ }^{4} \mathrm{~A}$ békeszerződés érvénybe lépését követően, 1921 őszén a SZKEB* Légügyi Ellenőrző Bizottsága megkezdte a Magyarországon található repülőanyag használhatatlanná tételét. Az év végéig 119 gépet és 77 motort semmisítettek meg, nagy mennyiségü szakfelszereléssel és gyártóberendezéssel együtt. Lebontottak 7 hangárt és számos reptéri létesítményt. A hangárok és kiszolgáló épületek egy részét a nemzetközi légi forgalom érdekeire hivatkozva, egy 1921. IX. 7-én megkötött hangár-szerződés révén sikerült megmenteni, olyan áron, hogy a repülési tilalom lejártáig a reptéri létesítmények használati joga a Szövetséges és Társult Hatalmakat illette. ${ }^{5}$

Az antant ellenőrei hamarosan feltárták a MAEFORT* katonai fedőjellegét is, és követelésük nyomán a társaságot 1921. XII. 6-án feloszlatták. A légierő területi kereteinek és reptéri szolgálatának rejtett fenntartása érdekében 1922. III. 1-jén reptérgondnokságokat állítottak fel 5 repülötéren (Mátyásföld, Székesfehérvár, Szombathely, Szeged, Miskolc). Ezt hivatalosan a nemzetközi légi forgalom kiszolgálásának biztosításával indokolták. Hatáskörükbe tartozott a repülöterek üzemeltetése, rádiószolgálat fenntartása, útlevél és vámügyek intézése. ${ }^{6}$

Magyarország közvetlen légügyi ellenőrzése 1922. XI. 17-én megszünt ugyan, a békeszerződésben elöírt korlátozásokra vonatkozóan azonban a SZKEB* továbbra is felügyeletet gyakorolt. A polgári repülési és repülógép-építési tilalmat feloldották, de szigorú szabályokat vezettek be a polgári repülőgépek teljesítményi mutatóit illetően. Az úgynevezett „kilences szabály” korlátozta a motorok teljesítményét, az elérhető maximális sebességet, repülési magasságot és távolságot, a hasznos terhelést stb., és ezzel megakadályozta korszerü repülőgépek tartását. A lehetőségekkel élve két új légiforgalmi vállalat alakult, a MALÉRT* és az Aeroexpress Rt., melyek a légi forgalom fenntartása mellett burkoltan katonai célokat is szolgáltak (hajózó és müszaki személyzet alkalmazása, katonai gépek és felszerelés raktározása, karbantartása). ${ }^{7}$

Magyarország légügyi szuverenitása elvben 1923. I. 1-jén helyreállt. A légi felségjog érvényesítése érdekében a magyar légtérben való közlekedés szabályairól 1922 XII. 14-én külön kormányrendeletet adtak ki. A légtér használatára, az idegen gépek átrepülésére csak a magyar légügyi

\footnotetext{
* Lásd mozaikszavak oldását.
} 
hatóság (KEM* XI. szakosztály) előzetes engedélyével kerülhetett sor. A légügyi szervezetek minden ilyen eseményröl tájékoztatták a $\mathrm{BM}^{*}$-et is. Külföldi katonai gépek csak a HM* külön engedélyével repülhettek át a magyar légtéren. ${ }^{8}$

1923. I. 1-jén az 5 müködö légi bázison repülötéri csendőr különítményeket állítottak fel, melyek légügyi igazgatási, légiforgalmi irányítási és légi rendészeti feladatokat láttak el. Hatáskörükbe tartozott a repülőterek, a gépek és a szállítmányok ôrzése, a fel- és leszállás engedélyezése, a pilóták és az utasok ellenőrzése. A Magyar Királyi Csendőrség 1921. VI. 3-tól hivatalosan már a BM* irányítása alatt állt. A reptéri csendőr különítmények a Vezényelt Csendőrosztag alárendeltségébe tartoztak. Bár ez az egység is a belügyi tárca költségvetéséből gazdálkodott, és állománya csendőr egyenruhát hordott, valójában rejtett katonai alakulat volt, és a honvédelmi tárca katonai csoportfőnöke rendelkezett felette. A személyi állomány a haderő soraiból került ki, de a csendőrségi státusz miatt nem számított bele a honvédség trianoni békediktátumban megszabott szükös létszámkeretébe. ${ }^{9}$

A légi forgalom és a légtérhasználat felügyeletére 1923. II. 1-jén légi ellenőrző szolgálatot szerveztek. A feladat ellátásába bevonták a katonai helyőrségeket, a pályaudvar- és hídőrségeket, a rendőrség, a csendőrség, folyamőrség és a vámőrség egységeit is. A vámőrség polgári és burkolt katonai feladatokat, határőrizetet és határvédelmet egyaránt ellátott, és a honvédség bizonyos egységeinek rejtésére is szolgált. ${ }^{10}$ A légtér ellenőrzését a kijelölt szervezetek egyelőre csak a földről végezték. A békeszerződés előírásai miatt repülőgépeket nem vonhattak be ebbe a tevékenységbe. A kisantant államok gépeinek rendszeres légi határsértései miatt azonban a magyar kormány kereste a lehetőséget a légi felségjog hatásosabb érvényesítésére. Így merült fel egy repülőgépekkel felszerelt légi rendvédelmi szervezetek létrehozásának gondolata. Légi rendőrség vagy csendőrség felállítását, felfegyverzett repülőgépek tartását azonban a SZKEB* semmilyen céllal nem engedélyezte. ${ }^{11}$

A polgári repülés (és a rejtett légierő) irányítására 1924. IV. 10-én létrehozták a LÜH*, amely egyben a rejtett magyar légierő vezető szervezeteként is szolgált. Ettől kezdve a LÜH* vette át a légi ellenőrző szolgálat felügyeletét is. A korábbi elképzelésekkel ellentétben a LÜH* nem önálló kormányhivatalként müködött, hanem a rejtés érdekében formálisan a $\mathrm{KEM}^{*}$ (valójában a $\mathrm{HM}^{*}$ ) alárendeltségébe tartozott, és részben az első fokú légügyi hatóság szerepét, részben a titkos légierő törzsének feladatait látta el. A hivatal nyílt állományát mindössze 20 fö alkotta, rejtett keretek között azonban további 178 fö (köztük 104 katona) vett részt a munkájában. ${ }^{12}$

A LÜH* 1924. XII. 13-án újraszabályozta a titkos légierő területi szerveiként müködő reptérgondnokságok, és a repülőtereken felállított csendőr különítmények feladatait, tevékenységét. Hét reptérgondnokságot szerveztek, melyek illetékességi köre megfelelt a 7 vegyesdandár, illetve a 7 csendör kerület területének, és székhelyük is megegyezett azok központjával. A repülötereken operatív szervként felállított csendőr különítmények központi parancsnoksága és hírközpontja Mátyásföldön müködött. A reptéri csendőrség alkalmazás szempontjából nem a csendőr kerület-parancsnokságok, hanem a LÜH* közvetlen alárendeltségébe tartozott. ${ }^{13}$ (I.sz. melléklet)

A légi ellenőrző szolgálat feladatai közé tartozott a légtér folyamatos ellenőrzése, a légi tevékenységről való rendszeres adatszolgáltatás, és ezzel együtt a figyelést végző személyzet háborús helyzetre való felkészítése, begyakoroltatása. A légi ellenőrző szolgálatot békében a repülő és légvédelmi alakulatok őrszemei, a helyőrségek, a pályaudvar- és hídőrségek, a rendőrség, a csendőrség, a folyamőrség, és a vámőrség felállított posztjai és mozgó járőrei látták el. A szolgálatba lépő őrségek egy-egy tagját külön légtérfigyelésre jelölték ki. A légi figyelőknek rögzíteniük kellett az észlelt gépek számát, fajtáját, hovatartozását, haladási irányát és tevékenységét, valamint a megfigyelés helyét és idejét. A figyelö őrsök és járórök észlelései alapján a helyi parancsnokságok havi légiforgalmi jelentést készítettek. Ezek adatait a vegyesdandárok és a kerület-parancsnokságok összegezték, és továbbküldték a LÜH* számára. ${ }^{14}$

A minden kétséget kizáróan idegen katonai gép észleléséröl az őrsök haladéktalanul tájékoztatták a légügyi hatóságot. Idegen repülőgépek (katonai vagy polgári) magyar területen történő leszállását szintén azonnal közölték a LÜH*-el. A beküldött jelentés tartalmazta a leszállt gép nemzetiségét, fajtáját, a személyzet kilétét, az induló és a célállomást, a leszállás helyét, időpontját és okát, a továbbhaladással kapcsolatos szándékot, és a földet éréskor bekövetkezett esetleges eseményt (sérülés, géptörés). A légi ellenőrzést végző közegek a leszálló katonai gépek személyzetét örizetbe vették. A polgári gépek pilótáit csak akkor, ha fényképezöt találtak náluk, tehát felmerülhetett a kémkedés gyanúja. Ilyen esetekben a további teendőkről a LÜH* intézkedett. ${ }^{15}$

Mozgósítás vagy katonai légvédelmi készültség elrendelése esetén a légi ellenőrző szolgálat mellett müködésbe lépett a honi légvédelmi figyelő és jelentő rendszer is. A légi figyelő hálózat 3

\footnotetext{
* Lásd mozaikszavak oldását.
} 
részből állt. A Budapest belterületén felállított őrsök, a fővárost körülvevő légvédelmi figyelőgyürü posztjai, ${ }^{16}$ illetve az országhatárok mentén felállított figyelőlánc alkotta. A fővárosi figyelőhálózat örsei a Citadellában elhelyezett OLP*, a többi egység a 7 vegyesdandár területi illetőségével megegyező 7 légvédelmi kerületi központnak jelentett. ${ }^{17}$ (I.sz. melléklet)

A légi közlekedésre vonatkozó nemzetközi elöírásokkal összhangban, 1924-ben Magyarországon részletes szabályozást vezettek be a légi forgalom minden fontos területén, a légtérhasználat, a lakott területek feletti átrepülés, a fel- és leszállás, a repterek müködése tekintetében. Meghatározták, hogy katonai repülőgépnek az olyan légi jármű tekintendő, amely katonai jelzéseket visel, szolgálatban lévő katonai személy vezeti, vagy a személyzete annak parancsnoksága alatt áll, illetve amelynek katonai jellege (a fegyverzete révén) egyértelmúen megállapítható. Az ilyen gépek Magyarország felett csak a HM* külön engedélyével közlekedhettek. ${ }^{18}$

A LÜH* a kiadott átrepülési engedélyekről az útvonal megjelölésével elöre tájékoztatta az érintett közigazgatási hatóságokat és rendvédelmi szervezeteket. Az engedély nélkül áthaladó gépekröl a légi ellenőrző szolgálat azonnal jelentést tett az illetékes reptérgondnokságnak és a LÜH*-nak. A LÜH* utasítására az engedély nélkül közlekedő légi jármüveket a magyar hatóságok leszállásra szólították fel, melyet rakétapisztolyból leadott, nappal fehér füstöt, éjszaka zöld fényt árasztó, 10 másodpercenként háromszor megismételt lövésekkel jeleztek. Amennyiben ez hatástalan maradt elvileg bármilyen más eszközt felhasználhattak a gépek leszállítására, de lőni rájuk csak a HM* által kiadott engedély alapján, tiszti rendfokozatú parancsnok közvetlen utasítására lehetett. ${ }^{19}$

A külföldi repülőgépeknek a rendszeres légi forgalmi járatok, illetve különleges esetek kivételével le kellett szállniuk az engedélyek ellenőrzése céljából valamelyik kijelölt magyar reptéren. ${ }^{20}$ Repülési probléma esetén a gépek szükségleszálló helyeket is igénybe vehettek. A határok felett történő be- és kirepüléshez „légi kapukat” állapítottak meg. ${ }^{21}$ (II.sz. melléklet) A külföldi gépek a légi kapuk között egyenes vonal mentén, illetve a kötelező leszállásra kijelölt repteret közbeiktató legrövidebb úton közlekedhettek. ${ }^{22}$

Egyes katonailag kiemelten fontos térségek felett tiltott övezetet jelöltek ki, melyeket a külföldi gépek nem érinthettek. ${ }^{23} \mathrm{~A}$ tiltott övezetek helyéről külön tájékoztatták az átrepülési engedélyt kérö személyeket. Ha egy külföldi gép véletlenül mégis behatolt egy tiltott terület fölé, a legközelebbi kijelölt reptéren köteles volt leszállni, hogy a magyar hatóságok ellenőrizhessék, nem folytatott-e kémtevékenységet. Amennyiben ezt elmulasztotta, a magyar légi ellenőrző szervek leszállást elrendelő jelzést adtak le a számára, és ha ez hatástalan maradt akár kényszerítő eszközöket is alkalmazhattak. ${ }^{24}$

A légvédelmi kerületek nevét 1924 augusztusában légvédelmi körzetre változtatták, és I-VII. római számmal jelölték. A légi figyelö és jelentő szolgálat az ország teljes területének lefedésére törekedett, a határok mentén lehetőleg hézagmentes figyelés biztosításával. A rendszer gyakorlati kiépítését azonban a haderőre vonatkozó nemzetközi korlátozások, a pénz- és személyzethiány hosszú időn át akadályozták. ${ }^{25} \mathrm{~A}$ súlyos létszámhiány miatt a figyelő posztok helyét úgy jelölték ki, hogy azok csendőr őrsök állomáshelyére essenek, és a beosztásra kerülő aktív keretállományt a csendőr legénység soraiból választották ki. Csak ahol nem volt csendőrség, oda vezényeltek honvéd legénységet. A csendőrség szervezete 1925-ben 7 kerületre, 30 osztályra, 93 szárnyra, 209 szakaszra, 853 őrsre tagolódott, állományában mintegy 12000 csendőr szolgált. ${ }^{26}$

Egy tervszerúen kiépített, közvetlen katonai irányítás alatt álló és speciálisan kiképzett személyzettel rendelkező légvédelmi figyelö- és jelentőhálózat hiányában a légtér megfigyelése az két világháború közötti időszakban alapvetően a légi ellenőrző szolgálatra hárult. Ennek a tevékenységével kapcsolatban azonban felmerültek bizonyos problémák. Az őrségek tagjai nem kaptak megfelelő felkészítést, így jelentéseik gyakran hiányosak és pontatlanok voltak. A vegyesdandárok a kötelező havi jelentéseket sokszor csak nagy késéssel juttatták el a légügyi hatósághoz. Ezekből általában hiányzott a tartalmi kiértékelés, és csak az örsök által közölt adatok statisztikai összesítését tartalmazták. Számos esetben előfordult, hogy egy berepülő gép többször is szerepelt a statisztikában, mert több őrstől is érkezett róla jelentés, holott a befutó hely és időpont adatok megfelelő összevetésével a mozgását pontosan követni lehetett volna. ${ }^{27}$

A kisantant államok repülőgépei rendszeresen megsértették a magyar légteret. Előfordult, hogy a gépek a rossz időjárás, illetve navigációs hiba miatt hatoltak be Magyarország fölé. Számos esetben azonban egyértelmü volt a tudatos légtérsértés, a felderítő szándék. A magyar fél diplomáciai tiltakozása nyomán az érintett államok rendszerint tagadták, hogy gépeik berepültek volna a magyar légtérbe. Így történt ez, amikor 1928. VIII. 6-án egy csehszlovák katonai gép alig 50 méter magasságból felvételeket készített Komáromról, illetve amikor 1932. VI. 6-án egy jugoszláv repülőgép 100-120 m magasból fényképezte a szőregi vasútállomást. ${ }^{28}$

\footnotetext{
* Lásd mozaikszavak oldását.
} 
A legsúlyosabb légtérsértésre 1931. VIII. 20-án került sor, amikor egy 3 gépes jugoszláv raj a magyar szervek engedélye nélkül, Zágrábból Budapest és Gyöngyös érintésével Kassára repült. Miközben a gépek háborítatlanul keresztül repülték az egész országot, egyikük elszakadt a köteléktől, és a szegedi reptéren szállt le. Mivel a gépen nem volt fegyverzet, a magyar hatóságok engedélyezték, hogy a személyzet hazarepüljön. A jugoszláv fél ezúttal hivatalosan is elismerte vétkességét. Az eset élesen rámutatott Magyarország kiszolgáltatottságára, hogy nem rendelkezik megfelelő eszközökkel a légi szuverenitásnak védelmére, és nem tudja megakadályozni, hogy a kisantant gépei az ország bármely városa fölé berepüljenek. ${ }^{29}$

A vesztes államok polgári repülését sújtó légügyi korlátozások 1926 végén megszüntek. Németország ugyanis bejelentette, hogy a vesztes országok repülögépeivel kapcsolatban elöírt teljesítményi limiteket, a győztes államok gépeire vonatkozóan is érvényesíteni fogja. Az annál nagyobb teljesítményű külföldi gépeket katonai légi járműnek tekinti, és kitiltja a német légtérből. Ez komoly gazdasági veszteséget okozott volna a nagyhatalmaknak, ezért a Nagykövetek Tanácsa új légügyi megállapodást kínált a vesztes államoknak. A korábbi szabályozás helyébe lépő párizsi egyezmény a katonai, vagy rendvédelmi célú felfegyverzett repülőgépek tartását továbbra is tiltotta. A kereskedelmi és sportrepülés számára azonban már lehetővé tette korszerü, nagy teljesítményü gépek beszerzését vagy gyártását. Az érintett kormányoknak azonban vállalniuk kellett a légi tevékenység pontos nyilvántartását, és a részletes adatszolgáltatást a Népszövetség számára. ${ }^{30}$

1927. III. 31-én megszünt Magyarország közvetlen katonai ellenőrzése. A SZKEB* szervezetei eltávoztak, a békeszerződés haderő korlátozására vonatkozó elöírásainak betartását az állandó kontroll helyett a magyar kormány által adott garancia és a Népszövetség eseti ellenőrzési joga szavatolta. ${ }^{31}$

Az ismétlődő csehszlovák légtérsértések miatt 1928 májusában a 3. (szombathelyi) vegyesdandár parancsnoka repülőgépek bevonását kezdeményezte a légi ellenőrző szolgálat ellátásába. Idegen gép berepülése esetén a Szombathelyen müködő repülőgép-vezető iskola Fokker C.V/D gépeit riasztották, melyek fegyverzet nélkül megközelítették a légtérsértő repülőt. Így lehetővé vált az idegen gép pontos megfigyelése, jelzéseinek leolvasása, ami fontos adatokat biztosított a berepülések miatti diplomáciai fellépéshez. A magyar repülőgépek megjelenése már önmagában is komoly elriasztó hatást gyakorolt. A kiképző gépek légtérellenőrző szerepkörben való alkalmazása nyomán már az első hónap után számottevően csökkent az illetéktelen berepülések száma az ország északnyugati körzetében. ${ }^{32}$

Az 1930-as évek elején szigorításokat vezettek be a légi ellenőrző szolgálat müködésében. A kisantant államok és a Szovjetunió katonai gépeinek átrepülését megtiltották. A polgári gépek légtérhasználati kérelme esetén a LÜH* már nem adta ki automatikusan az engedélyt, hanem a személyzetet előzetesen leinformálták. A légi ellenőrzést végző szervezetek közül a csendőr szakaszok az illetékes csendőr kerületparancsnokságnak, a BM* VI. b. osztályának és a LÜH*-nak jelentettek. A vámőr szakaszok a vámőr kerület-parancsnokságokon át, a PM* XIX. osztálya által a LÜH* részére küldtek tájékoztatást. A helyi honvéd parancsnokságok a vegyesdandárok közvetítésével a $\mathrm{HM}^{*}$ Elnökségéhez juttatták el a légi eseményekkel kapcsolatos jelentéseket. A légi kapuk rendszerét 1932-ben átalakították, ${ }^{33}$ (II.sz. melléklet) egy-egy $5 \mathrm{~km}$ széles folyosón, a határon átvezető fő közlekedési útvonalak, illetve vasútvonalak felett.

1929-ben módosították az idegen repülők számára tiltott övezetek határát. Négy át nem repülhető zónát jelöltek ki. ${ }^{34}$ (III.sz. melléklet)

Komoly problémát jelentett az ország területén végrehajtott illegális leszállások. A helyi hatóságoknak a repülőtéren kívül leszálló gépek távozását minden eszközzel meg kellett volna akadályozniuk. A gyakorlatban azonban mire a hivatalos szervezetek tudomást szereztek a leszállásról és a rendvédelmi közegek a helyszínre értek, az idegen gép már általában továbbrepült. Ezért a BM* 1929-ben elrendelte, hogy a közigazgatási szervezetek a polgári lakosságot is igénybe vehetik az ilyen gépek visszatartását célzó intézkedéseknél. A lakosságot tájékoztatták, hogy idegen gép leszállásakor azonnal értesíteni kell a legközelebbi hatósági személyt, és annak megérkezéséig minden rendelkezésre álló eszközzel vissza kellett tartani a légi járművet. Ha egy leszálló idegen gép észlelése során felmerült a kémkedés gyanúja, azonnal jelentsék ezt a területileg illetékes vegyesdandár sajtóelőadójának (kémelhárító tisztjének) is. ${ }^{35}$

Történt bizonyos elörelépés a légvédelmi figyelő, jelentő és riasztó szolgálat kiépítése terén is. A VKF* ezzel kapcsolatban 1929-es állásfoglalásában hangsúlyozta, hogy bár a szervezet csak a felriasztást követően kezd teljes aktivitással müködni, tevékenységét már békében elö kell késziteni. A vegyesdandárok légvédelmi parancsnokai mellett és a repülőtereken müködő hírközpontoknak, illetve a kulcsfontosságú helyekre, például a föváros térségébe telepített örsöknek már békében is szolgálatot kell teljesíteniük. ${ }^{36} \mathrm{Az}$ 1929-es tervek 113 figyelő őrs felállításával számoltak. A hálózat teljes

\footnotetext{
* Lásd mozaikszavak oldását.
} 
kiépítéséhez azonban nem állt rendelkezésre elegendő pénz, felszerelés és kiképzett állomány. Így a légi figyelő szolgálat az 1930-as évek első felében egyelőre csak részlegesen volt müködőképes. ${ }^{37}$

A gyakori csehszlovák és jugoszláv légtérsértések által leginkább érintett körzetekben illetékes 3. (szombathelyi), 5. (szegedi) és 7. (miskolci) vegyesdandár parancsnoka 1931 nyarán ismételten kérte, hogy a minden kétséget kizáróan idegen katonai gépekkel szemben fegyveresen is felléphessen, bevethesse a légvédelmi tüzérséget, vagy a repülőket. Hangsúlyozták, hogy ennek hiányában a szomszédos országok pilótái a magyar légteret a ,senki földjének“ tekintik, ahol minden korlátozás nélkül, szabadon repülhetnek. ${ }^{38}$

A jogosulatlan berepülések visszaszorítása érdekében 1931. IX. 24-én a LÜH* javaslatot tett egy légi csendőr repülőszázad felállítására, Mátyásföldön. Az egység feladata részben a polgári légi közlekedés ellenőrzése, részben a légtér védelme lett volna. A légi csendőrséget emellett belső karhatalmi feladatok ellátására is szánták, ami közvetlenül a biatorbágyi merénylet után szintén fontos szempont volt. A VKF* azonban ellenezte a tervet, nem akarta felfedni, hogy az ország rendelkezik katonai gépekkel, és a rendelkezésre álló kis számú légierőt nem kívánta rendvédelmi feladatok ellátására lekötni. Így a légi csendőrség felállítása egyelőre lekerült a napirendről. ${ }^{39}$

A LÜH* 1933-ban új szabályozást vezetett be a külföldi légi járművek Magyarország feletti közlekedésével kapcsolatban. Az új rendelet kiadása előtt részletes egyeztetésre került sor valamennyi érintett tárcával azaz a honvédelmi, a belügyi, a pénzügyi és a kereskedelemügyi tárcákkal. A magyar légtérbe történő berepülésre a LÜH* adott ki hivatalos engedélyt, miután a kérelmező pontos adatokat közölt a tervezett útvonalra, illetve a pilóták és az utasok személyére vonatkozóan. A Magyarországgal légügyi egyezményt kötött államok polgári gépei előzetes engedély nélkül, de a légiforgalmi szabályokat betartva használhatták a magyar légteret. ${ }^{40}$ A katonai repülőgépek berepülését a honvédelmi tárca engedélyezte, egyeztetve a külügyi szervezetekkel és a LÜH* illetékeseivel. Katonai felszerelés (fegyver, lőszer, bomba, vegyi harcanyag) polgári gépeken történő átszállításához a belügyi tárca különleges engedélyére volt szükség, melyben megjelölték a szükséges biztonsági rendszabályokat. Személyi védőfegyver viseléséhez a LÜH* jóváhagyását kellett kérni. Ugyancsak a légügyi hatóság adhatott engedélyt fényképezőgép vagy postagalamb átszállítására is, de csak olyan módon elhelyezve, hogy az Magyarország felett ne legyen használható. ${ }^{41}$

A be- vagy átrepülés engedélyezésének alapfeltétele volt a jól látható nemzeti jelzés és az egyéni lajstromjel. A repülőgépek csak a kijelölt légi kapukon keresztül közlekedhettek, olyan magasságban, hogy jelzéseik a földről jól azonosíthatók legyenek. A gépek az elöre megadott útvonalon haladhattak, leszállásra a kijelölt vámreptereket vehették igénybe. Más helyen végrehajtott kényszerleszállás esetén a személyzetnek haladéktalanul jelentkeznie kellett a legközelebbi rendőr- vagy csendőrhatóságnál. Ilyenkor a magyar hatóságok ellenőrizték a személyzet adatait, az átrepülés jogosultságát, és átvizsgálták a gépet, nincs-e a fedélzeten engedély nélküli rádió- vagy fényképező készülék, illetve hadianyag. Ha mindent rendben találtak, a szükséges javítás, üzemanyag feltöltés után a gépet továbbengedték. Ha bármilyen problémát tapasztaltak, a LÜH* újabb utasításáig visszatartották a gépet. Katonai légi jármü esetén a leszállásról és az ellenőrzésről a honvédelmi tárcát is haladéktalanul tájékoztatták. A továbbutazást ez esetben csak a honvédelmi tárca engedélyezhette. ${ }^{42}$

Ha egy külföldi gép berepült valamelyik kijelölt tilos légi zóna fölé a hatóságok a legközelebbi reptéren történő leszállásra utasították. Ezt nappal három 10 másodpercenként kilött, fehér füstöt árasztó lövedékkel jelezték. Éjjel fehér csillagokat szóró lövedéket alkalmaztak. A leszállás után a reptéri csendőrkülönítmény átvizsgálta a gépet, nem folytatott-e felderítést, titkos képrögzítést. Az ellenőrzés eredményét polgári gép esetén a légügyi hatósághoz továbbították. Katonai gép esetén elöször az illetékes vegyesdandárt értesítették, amely indokolt esetben kémelhárító közegeket küldött a helyszínre. Ha az érintett légi jármü a felszólítás ellenére nem szállt le a légügyi szervezetek másodszor is figyelmeztették, nappal sárga füstöt árasztó, éjszaka zöld csillagokat szóró lövedékek kilövésével. Amennyiben erre sem reagált, bármilyen eszközzel, akár fegyveres erővel is a földre lehetett kényszeríteni. Békeidőben azonban a fegyverhasználatra, a vadászrepülök vagy a légvédelmi tüzérség bevetésére a $\mathrm{HM}^{*}$ Katonai Főcsoportfőnöksége közvetlen engedélyére volt szükség. ${ }^{43}$

Az 1930-as évek közepén Magyarország légi veszélyeztetettsége tovább növekedett. A kisantant államok 1933-ban 2410, 1936-ban 2848 katonai repülőgéppel rendelkeztek. Ezek a gépek összpontosított támadás esetén a háború első órájában 280 t bombát dobhattak Magyarország területére. A légitámadások súlyos nehézségeket okozhattak volna a magyar haderő mozgósításában, felvonulásában, a közigazgatás müködésében, a közúti és vasúti forgalomban, a lakosság ellátásában. ${ }^{44} \mathrm{Az}$ európai államok légitámadás iránti érzékenységét tekintve, hogy területüket a szomszédos államok

\footnotetext{
* Lásd mozaikszavak oldását.
} 
légiflottái milyen mértékben veszélyeztetik, Magyarország volt a legkedvezőtlenebb helyzetben, mert egész területe a potenciális ellenfelek (a kisantant államok) repülőgépeinek hatósugarán belül esett. ${ }^{45}$

A kisantant országok repülöi által elkövetett légtérsértések száma és a cselekmények súlyossága az 1930-as évek közepén tovább növekedett. 1935. IX. 24-én egy Potez P-25-ös katonai román felderítő gép szállt le Debrecen közelében, majd rövid tájékozódás után, a felszállását megakadályozni igyekvő civileket géppuskával sakkban tartva, visszarepült Romániába. A hivatalos tiltakozásra válaszolva Bukarest egyszerüen letagadta a légtérsértés tényét. 1936-ban egyedül a csehszlovák repülőgépek 45 esetben repültek be jogosulatlanul Magyarország fölé. ${ }^{46} \mathrm{~A} \mathrm{VKF}^{*}$ már 1935 decemberében felhívta a figyelmet, hogy a sorozatos engedély nélküli berepülésekkel szemben erőteljesebb fellépésre lenne szükség. Ha általános fegyverhasználatról nem is lehet szó, egy-egy különösen fontos körzetben, az elöírt figyelmeztető jelzések leadása után engedélyezni kellene a tüz megnyitását a légtérsértő gépekkel szemben. A honvédelmi tárca azonban a kiszámíthatatlan diplomáciai következményekre hivatkozva elvetette a javaslatot. ${ }^{47}$

A légi szuverenitás kérdését és a légi ellenőrző szolgálat tevékenységét érintő rendelkezések többszöri módosítását követően, 1935-ben új átfogó szabályozást adtak ki. A légi forgalom ellenőrzése továbbra is a LÜH* hatáskörébe tartozott, amely ennek ellátása során szükség szerint igénybe vehetett különböző hatóságokat és rendvédelmi szerveket. Minden felállított őrség vagy mozgó járőr naponta jelentést tett a honvéd állomás-parancsnokságoknak, illetve a helyi rendőr-, csendőr-, folyamőr-, illetve az 1932. X. 1-jén felállított határör-parancsnokságoknak. ${ }^{48} \mathrm{Az}$ idegen légi járművekről az örségek légi tevékenységi jelentést készítettek, melyben rögzítették azok polgári vagy katonai jellegét, számát, jelzését, típusát, fajtáját (szárnyak, motorok számát), útirányát, repülési magasságát és magatartását. Különösen fontos volt a gépen szereplő egyéni jelzések (betủk, számok) feljegyzése, mert a diplomáciai fellépés során ezt lehetett pontosan azonosítani. A jelentések tartalmazták a megfigyelés helyét és idejét és a szemtanúk adatait is. Ha az észlelt légi jármủ láthatólag megszegte a légiforgalmi elöírásokat, berepülése jogosságával kapcsolatban kétely merült fel vagy valamilyen rendkívüli esemény történt vele, arról azonnal tájékoztatni kellett az illetékes vegyesdandárt. ${ }^{49}$

A külföldi gépek reptéren történő leszállása során az utasok ellenőrzésébe a reptéri csendőrség mellett bekapcsolódtak a VKF*2/D (kémelhárító) osztály kirendelt közegei is. A személyzettől esetleg elkobozásra kerülő térképeket, rajzokat, filmeket a LÜH* helyett szintén a VKF* 2 vette át. Repülőtéren kívül történő leszállás esetén az igazoltatásra hivatott rendvédelmi szervezetek értesítették a területileg illetékes vegyesdandár defenzív tisztjét, aki a gép továbbengedése előtt kémelhárítási szempontból megvizsgálta a leszállás okát és körülményeit. Olyan körzetekben, ahol sem honvéd alakulat, sem rendőrség vagy csendőrség nem állomásozott, a légi ellenőrzés végrehajtásába a belügyi tárca javaslatára bevonták a helyi tüzoltóságot. A tüzoltó testületek felkészítéséről, megfelelö segédletekkel és felszereléssel (távcső) történő ellátásáról a belügyi tárca gondoskodott. ${ }^{50}$

A légi ellenőrzés hatékony végrehajtását azonban továbbra is számos probléma nehezítette. A PM* adatai szerint 1935-ben csak a határőrizeti szervezeteket tekintve 795 megfelelö távcsőre lett volna szükség, de csak 440 állt rendelkezésre. A mozgó ellenőrző közegek kerékpárszükséglete 1048 $\mathrm{db}$ volt, amiből $300 \mathrm{db}$ hiányzott. Az útellenőrző őrsöknek csak 42\%-a rendelkezett telefonnal, amivel a repülőesemények észleléséről azonnal tájékoztathatták a felettes szerveket. A jogosulatlanul berepülő vagy a légiforgalmi szabályokat megsértő gépek leszállásra történő felszólításához nem állt rendelkezésre kellő mennyiségü jelzőpisztoly és különleges löszer. ${ }^{51}$

A HM* Elnöksége az érintett szervezetek bevonásával 1935. X. 30-án külön értekezletet tartott a légi ellenőrző szolgálat hatékonyságának növelése érdekében. Döntés született a szolgálat ellátásához szükséges megfigyelő és jelzőeszközök (távcső, jelzőpisztoly) számának fokozatos bővítéséről. A tervek között szerepelt, hogy a figyelő szervezeteket fényképezőgéppel is ellátják, hogy a légtérsértések tényét a későbbi diplomáciai eljáráshoz bizonyító erővel dokumentálni lehessen. A légi kapuk határait a levegőből jól látható módon, a földön is kijelölték, megkönnyítve ezzel mind a repülők, mind az ellenőrző közegek tájékozódását. Lépések történtek a légi figyelést végző személyzet speciális kiképzésére, amely során nemcsak a gépek azonosítását, hanem a repülőesemények adatainak pontos rögzítését is gyakorolták. Elrendelték, hogy jogosulatlan légtérhasználat esetén a légi ellenörzést végző szervezetek a jelentéseik továbbításához a postai távbeszélő vonalakat elsőbbséggel használhatják. ${ }^{52}$

A honvédelmi tárca fontosnak tartotta a diplomáciai fellépés meggyorsítását, amire korábban csak az esetek részletes kivizsgálását követően, gyakran fél éves késéssel került sor. Az új rendelkezések szerint a jogosulatlan légtérhasználat gyanújáról érkező bejelentés után a honvédelmi tárca Elnöksége utasította az

\footnotetext{
* Lásd mozaikszavak oldását.
} 
érintett országban müködő katonai attasét, hogy jelentsen be „előzetes tiltakozást”, azzal, hogy a részletes kivizsgálás után a magyar KÜM* hivatalos jegyzéket fog küldeni. Bár utóbb az attasék által jelzett légtérsértések 25-30\%-ában sikerül csak olyan konkrét adatokat gyüjteni, amire diplomáciai fellépést lehetett alapozni, ez a megoldás azonban a korábbinál még így is hatékonyabbnak bizonyult. Az azonnali fellépés a honi légi ellenőrző szervezetek felkészültségét és éberségét is jól demonstrálta. ${ }^{53}$

A tilos zónákban és más olyan körzetekben, ahol kiemelt fontosságú katonai objektumok vagy hadiüzemek voltak, leszállásra felszólító jelzö lövegek felállítását határozták el. A rendszeresített $8 \mathrm{~mm}$ es rakétapisztoly lövedéke ugyanis csak kis magasságból volt látható, az 1000 m felett repülő gépeknek csak légvédelmi löveggel lehetett jelezni. A honvédelmi tárca már 1935 elején elrendelte, hogy a Tisza-Sajó szöge és a diósgyőri iparvidék felett ismétlődő csehszlovák berepülések csökkentése érdekében a miskolci tüzérlaktanyában tartsanak készenlétben egy $8 \mathrm{~cm}$-es $29 \mathrm{M}$. légvédelmi löveget, amely a légtérsértésről érkező jelentés nyomán leszállásra felszólító jelzést lőhet fel. Hasonló megoldást vezettek be a Györ-Mosonmagyaróvár körzetébe berepülö csehszlovák gépek távoltartására is. ${ }^{54}$

A légi ellenőrzés irányításában 1936 folyamán változás következett be. A LÜ̈H* szabadulni igyekezett ettől a terhes feladattól, és kezdeményezte, hogy ezt a tevékenységet már békeidőben is vegye át az OLP*. Részben, mert háborús helyzetben amúgy is az OLP* szervezetei látják el a légtér figyelését, részben pedig, mert a légtérsértések megakadályozásához szükséges eszközök felett (légvédelmi tüzérség, honi vadászrepülők) is az OLP* rendelkezik. Az OLP* viszont szükös anyagi és személyi lehetőségei, és más területen is szaporodó feladatai miatt megpróbálta elhárítani a légi ellenőrzés átvételét. Hangsúlyozta, hogy a külföldi gépek átrepülési engedélyét a LÜH* adja ki, így könnyebben ki tudja szürni a jogosulatlan légtérhasználatot. A vitát végül a VKF* döntötte el, amely a légi ellenörzés irányítását az OLP* hatáskörébe utalta. ${ }^{55}$

Lépések történtek a háborús körülmények között aktivizálódó honi légvédelmi figyelö- és jelentőszolgálat kiépítése terén is. E szolgálat feladatkörébe tartozott az ország feletti ellenséges repülömozgások megfigyelése, a katonai légvédelem megfelelő adatokkal történő ellátása, légitámadás veszélye esetén a légoltalmi közületek riasztása. A figyelö hálózat alulról fölfelé 4 szintből tevődött össze, a figyelő őrsökből, a légvédelmi szárnyközpontokból, a 7 Légvédelmi Kerületi Központból és az Országos Légvédelmi Központból. (IV.sz. melléklet) A légvédelmi figyelö- és riasztószolgálat keretében 1935-ben 250 örs felállítását tervezték (117 a határok mentén, 133 a fontosabb közigazgatási, közlekedési és gazdasági centrumok körül). Egyes szakértők szerint azonban az ország területének teljes lefedéséhez, és a határok mentén felállítandó többsoros vonal kialakításához legalább 500 őrsre lett volna szükség. Komoly terhet jelentett azonban a tervezett 250 örs felállítása is, melynek személyi szükséglete 4198 fö volt, anyagi tekintetben pedig 1187776 pengöt igényelt. ${ }^{56}$

A légi szuverenitás védelme érdekében az OLP* 1936-ban ismét kezdeményezte a légi csendőrség létrehozását. A szomszédos Ausztriában már évek óta müködött egy légi rendör repülő század. A légi csendőrség megszervezése azonban több nehézségbe ütközött. Nem lehetett komolyabb eröt elvonni erre a célra az amúgy is kis számú légierőtől. A bázisok kiépítése, az egységek üzemeltetése, a megfelelő híradóhálózat megteremtése jelentős anyagiakat igényelt. Komoly diplomáciai előkészítésre volt szükség, hogy el lehessen kerülni a külpolitikai bonyodalmakat. Az ügyben végül olyan döntés született, hogy felfegyverzett repülőgépeket 1937 tavaszától állítanak szolgálatba, kísérletképpen, egyelőre a Tisza-Sajó szögében. A feladatot a Miskolc és Nyíregyháza térségében állomásozó vadászrepülő alakulatok látják el, századonként 1-1 géppárral. ${ }^{57}$

Az 1938 augusztusában sorra kerülő bledi tárgyalásokon a kisantant államok elismerték Magyarország fegyverkezési egyenjogúságát. Ez alapvetően új helyzetet teremtett a légi ellenőrző szolgálat müködése terén is. Megkezdődött a légierő, a légvédelem és a katonai figyelö- és jelentőszolgálat nyílt fejlesztése. 1938. IX. 30-án a VKF* elrendelte, hogy a Budapest körzetébe berepülő ellenséges (csehszlovák) katonai gépek elfogására a honi vadászrepülő erők bevethetők. 1938. X. 18-án ezt azzal egészítették ki, hogy a légvédelmi erők külön engedély nélkül is tüzet nyithatnak azokra az ország fölé berepülö csehszlovák, szovjet, illetve felségjelzés nélküli gépekre, amelyek nem engedelmeskednek a magyar légi ellenőrző szervezetek felszólításának, és nem hajlandóak leszállni a legközelebbi reptéren. A más nemzetiségü gépek esetében viszont a légi ellenőrzés hagyományos (nem fegyveres) formáit alkalmazták a magyar hatóságok. Az ilyen ügyeket továbbra is diplomáciai csatornákon kívánták rendezni. ${ }^{58}$

A légtér ellenőrzésének fokozottabb biztosítása érdekében a Légierő Parancsnoksága 1939 júniusában kidolgozta a légi csendörség feladataira, szervezetére és müködésére vonatkozó részletes tervezetet. Ezek szerint az új rendvédelmi szervezet hatáskörébe tartozott a légtérsértések meggátlása, a jogosulatlanul berepülő gépek visszafordulásra vagy leszállásra kényszerítése, a kémtevékenységnek vagy az ellenséges

\footnotetext{
* Lásd mozaikszavak oldását.
} 
propagandaanyagok terjesztésének megakadályozása, illetve a légi közlekedés ellenőrzése, szabályainak betartatása, a légi forgalommal kapcsolatos közbiztonsági feladatok ellátása. Az új szervezet — a Magyar Királyi Csendőrség részeként, napjaink fogalmai szerinti — szakszolgálati ágként Magyar Királyi Légi Csendőrség elnevezéssel 1940. VI. 1-jével kezdte meg a müködését. ${ }^{59}$ A szervezet 5 repülő osztagot foglalt magában, melyek a szolnoki, a nyíregyházi és a budaörsi reptéren állomásoztak. A repülő egységek személyi állományát 8 tiszt és 42 fő legénység alkotta. A légi csendőrség földi részlege az ország 22 állandó repülőterén müködö, általában 6-15 fös őrsökből vagy 3-5 fös különítményekből állt. A szervezet földi részlegének személyi állományát 5 tiszt és 156 fő legénység képezte. ${ }^{60}$ (V.sz.melléklet)

A II. világháború kirobbanása, majd Magyarország hadba lépése nyomán a polgári légi ellenőrző szolgálat önálló szerepe megszünt, feladatait a katonai légvédelmi figyelő- és jelentőszolgálat vette át, amely 1941. júniusában 9 légvédelmi központtal és 346 honi légvédelmi figyelőőrssel, 1944 márciusában pedig már 15 légvédelmi központtal és 550 örssel rendelkezett. ${ }^{61}$ (VI.sz. melléklet)A rendvédelmi szervezetek továbbra is részt vettek a légtér megfigyelésében, ezt a tevékenységet azonban ekkor már a polgári légoltalomhoz, illetve a MÁV* és a MFTR* figyelőszolgálatához hasonlóan, a katonai légvédelemmel szoros együttmüködésben, a honvédség irányítása mellett folytatták.

Mozaikszavak oldása:

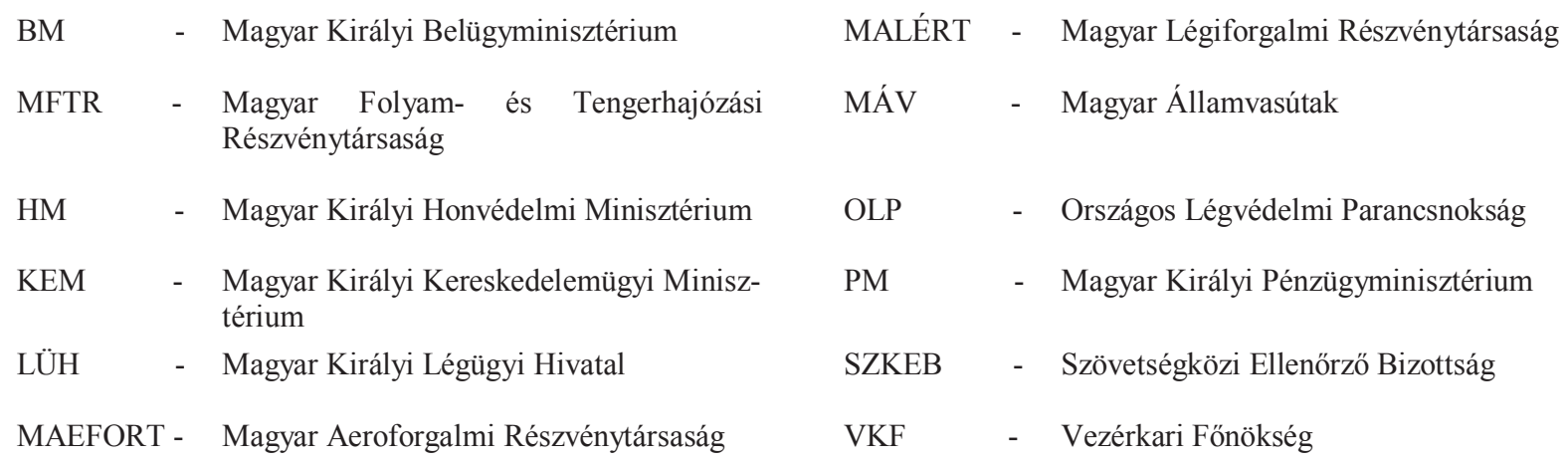

Jegyzetek:

${ }^{1}$ Moys: 169-170.p.

${ }^{2}$ HIM-HL HM Eln. D. 5695/1922. ; AlKér - AmbrózY: 54., 60., 63.p. ； Sillay: 128-129.p.

${ }^{3}$ BERKOVICS: 17.p.

${ }^{4}$ HIM-HL VKF Eln. 1. 91/1921. ; HIM-HL TGY 2787. I. rész. 13-14., 21-26.p.

${ }^{5}$ HIM-HL PERS VII. 87. C-1.

${ }^{6}$ HIM-HL HM op.cit. Eln. D. 5695/1922. ; HIM-HL PERS op.cit. VII. 87. C-1.

${ }^{7}$ HIM-HL HM op.cit. Eln. D. 19 670/1922., 18 137/11923. ; SZENTNÉMEDY: 71.p.

810 270/1922. (XII. 14.) ME.r.

${ }^{9}$ HIM-HL VKF op.cit. Eln. 1. 6117/1924.

${ }^{10}$ PARÁDI: Nemzeti határörizetünk polgári szakasza. 147.p.

${ }^{11}$ HIM-HL HM op.cit. Eln. D. 15 764/1923. ; HIM-HL VKF op.cit. Eln. 1. 6166/1924.

${ }^{12}$ M. SZABÓ: 9-10.p. ; HÉJJAS: 130-131.p.

${ }^{13}$ Repülőtérgondnoksági csendőr különítmények müködtek: 1. Budapest, 2. Székesfehérvár, 3. Szombathely, 4. Pécs, 5. Szeged, 6. Debrecen, 7. Miskolc

HIM HL TGY op.cit. 2787. II. rész 19.p. ; KAISER: 59.p. + 164.p.

${ }^{14}$ HIM-HL TGY op.cit. 3715. 138.p.

${ }^{15}$ HIM-HL VKF op.cit. Eln. Főv. 259/1922.

16 A fővárost körülvevő légvédelmi figyelő gyűrủ állomáshelyek voltak: Vác, Balassagyarmat, Salgótarján, Gyöngyös, Jászberény, Szolnok, Cegléd, Dunaföldvár, Székesfehérvár, Komárom, és Esztergom térségében.

Loc.cit. Eln. Főv. 259/1922. ; HIM-HL TGY op.cit. 2974. I. rész 30.p.

${ }^{17}$ Légvédelmi kerületi központok müködtek: 1. Budapest, 2. Székesfehérvár, 3. Szombathely, 4. Pécs, majd Kaposvár, 5. Szeged, majd Kiskunfélegyháza, 6. Debrecen, majd Szolnok, 7. Miskolc.

Loc.cit.

${ }_{18}^{16}$ 1630/1924. (II. 22.) ME.r. ； 45 332/1924. (II. 25.) KEM.r.

${ }^{19}$ SiLLAY: op.cit. 123.p. $+131-132 . p$.

${ }^{20}$ Külföldi légiforgalmi járatok magyarországi kijelölt leszállóhelyei voltak: Mátyásföld, Miskolc, Szeged, Szombathely. MOL K 150. BM Eln. 1924-V-7945.

\footnotetext{
* Lásd mozaikszavak oldását.
} 
${ }^{21}$ Repülési gondok esetén Albertfalva, Debrecen, Pécs, Székesfehérvár repülőterek szükségleszállóhelyekként müködtek. Loc.cit.

${ }^{22}$ A magyar határt a repülőgépek az úgynevezett légikapuk térségében repülhették át. Légikapukat határoztak meg: Sátoraljaújhely, Nyírábrány, Kétegyháza, Szeged, Mohács, Murakeresztúr, Szombathely, Mosonmagyaróvár és Komárom térségében.

Loc.cit.

${ }^{23}$ Ilyennek számított Budapest belvárosa, a Csepel-sziget északi része, Lajosmizse - Újhartyán - Kunpeszér térsége, illetve a Balatonfüzfö - Váloslőd - Kisbér - Székesfehérvár által határolt terület.

HIM-HL VKF op.cit. Eln. 1. 6740/1925. ; SILlaY: op.cit. 123.p. + 131-132.p.

${ }^{24}$ Loc.cit.

${ }^{25}$ HIM-HL VKF op.cit. Eln. 1. 6551/1924. ; BERKOVICS: op.cit. 60.p.

${ }^{26}$ PARÁDI: A Magyar Királyi Csendőrség szervezete. 85.p.

${ }^{27}$ HIM-HL VKF op.cit. Eln. 1. 6448/1925., 6834/1925.

${ }^{28}$ Loc.cit. Eln. 1. 5597/1928.; HIM-HL HM op.cit. Eln. B. 4308/1932.

${ }^{29}$ HIM-HL HM op.cit. Eln. B. 7816/1931., 7939/1931.

${ }^{30}$ HIM-HL VKF op.cit. Eln. 1. 4082/1927. ; SILLAY: op.cit. 129.p.

${ }^{31}$ HIM-HL HM op.cit. Eln. B. 8159/1927.

${ }^{32}$ HIM-HL VKF op.cit. Eln. 1. 5504/1928., 105 804/1929.

33 A légikapuk 1932. évi átrendezését követően Hegyeshalom, Szombathely, Kelebia, Zákány, Battonya, Mezőkeresztes, Hidasnémeti és Komárom térségében lehetett a Magyar Királyság határán átrepülni.

HIM-HL HM op.cit. Eln. B. 5350/1932., 104 986/1932.

${ }^{34}$ Az idegen repülök számára az 1939. évi módosítást követően négy tiltott övezet határa volt: az egyik a Balaton északi csúcsa, Városlőd, Kisbér, Bodajk és Székesfehérvár között húzódott. A másik az Újhartyán, Lajosmizse, Kerekegyháza, Peszérpuszta közötti területet fedte le. A harmadikat Budafok körzetében jelölték ki. A negyedik Csepel térségét foglalta magába, amit a sziget északi szeglete, a Sashegy, a Háros-sziget délnyugati csúcsa, Soroksár déli kijárata és a Duna mellékágának nyugati partja határolt.

Loc.cit. Eln. I. 106 083/1930. ; HIM-HL VKF op.cit. Eln. 1. 1080/1931.

${ }^{35}$ MOL K 149. op.cit. BM Eln. Res. 1931-VII-9284. ; HIM-HL VKF op.cit. Eln. 1. 105 732/1929.

${ }^{36}$ HIM-HL VKF op.cit. Eln. Hdm. 1929. sz. n.

${ }^{37} \mathrm{Az}$ 1. (budapesti) légvédelmi körzet figyelő rendszere a föváros belterületén 5, Budapest körül 15 örhelyből állt. A 2. (székesfehérvári) körzet 15, a 3. (szombathelyi) 15, a 4. (pécsi) 14, az 5. (szegedi) 16, a 6. (debreceni) 18, a 7. (miskolci) 15 örssel rendelkezett.

Loc.cit. Eln. 3.33 369/1932. ; HIM-HL TGY op.cit. 3715. 153.p.

${ }^{38}$ HIM-HL HM op.cit. Eln. B. 7587/1931.

${ }^{39}$ Loc.cit. Eln. B. 7410/1931., 7903/1931.

${ }^{40}$ Magyarországgal légügyi egyezményt kötött Ausztria, Lengyelország, Németország, Olaszország.

Loc.cit. Eln. I. 452/1933. ; 115 000/1933. (XII. 22.) KEM.r.

${ }^{41}$ Loc.cit. Eln. I. 452/1933.

${ }^{42}$ HÉJJAS: op.cit. 85-86.p.

${ }^{43}$ HIM-HL HM op.cit. Eln. I. 452/1933.

${ }^{44}$ HIM-HL VKF op.cit. Eln. 2. 121 429/1935. ; HALÁSZ: 16-17p. ; ERdéLYi: 17.p.

${ }^{45}$ RÉCZEY: 116.p. ; FABINI: 137-138.p.

${ }^{46}$ HIM-HL HM op.cit. Eln. II. 7733/1935., 9648/1935.

${ }^{47}$ Loc.cit. Eln. I. 124 904/1935. ; HIM-HL VKF op.cit. Eln. 1. 1325/1936.

${ }^{48}$ HIM-HL VKF op.cit. Eln. 1. 1224/1934., 1031/1935.

${ }^{49}$ Loc.cit. Eln. 1. 1224/1934.

${ }^{50}$ Loc.cit. Eln. 1. 1224/1934.

${ }^{51}$ Loc.cit. Eln. 1. 1031/1935.

${ }^{52}$ HIM-HL HM op.cit. Eln. I. 124 270/1935.

${ }^{53}$ Loc.cit. Eln. I. 124 270/1935.

${ }^{54}$ HIM-HL VKF op.cit. Eln. 1. 1577/1935.

${ }^{55}$ Loc.cit. Eln. 1. 1140/1936.

${ }^{56}$ HIM-HL HM op.cit. Elns. 14 608/1936. ; TóTH: 102.p. ; FinTOR: 124.p.

${ }^{57}$ HIM-HL VKF op.cit. Eln. 1. 1577/1936. ; HIM-HL TGY op.cit. 2787. IV. rész 203.p.

${ }^{58}$ HIM-HL VKF op.cit. Eln. 1. 3309/1938. ; Loc.cit. Hdm. 381 018/1938.

${ }^{59}$ Loc.cit. Eln. 1. 4611/1939., 4672/1939.

${ }^{60}$ Loc.cit. Eln. 1. 3655/1940. ; HIM-HL TGY. op.cit. 2787. V. rész 25.p.

${ }^{61}$ HIM-HL VKF op.cit. Eln. 1. 5122/1941., 6948/1941. ; Loc.cit. Eln. Om. 26/1943. 
Jegyzetekben alkalmazott röviditések:

MONOGRÁFIÁK. KISMONOGRÁFIÁK ÉS HASONLÓ JELLEGÜ KÖTETEK

ERDÉLYI

HALÁSZ

HÉJJAS

KAISER

M. SZABÓ

SZENTNÉMEDY

\section{TANULMÁNYOK}

FABINI

FINTOR

MOYS

PARÁDI: A Magyar Királyi Csendőrség Szervezete.

PARÁDI: Nemzeti határőrizetünk polgá- ri szakasza.

RÉCZEY

SiLlay

ТóтH

\section{KÉZIRATOK}

BERKOVICS

\section{DOKUMENTUMKIADVÁNY}

ALKÉR - AMBRÓZY

\section{LEVÉL- IRAT- ÉS DOKUMENTUMTÁRI GYÜJTEMÉNYEK}

HIM-HL HM

HIM-HL PERS

HIM-HL TGY

HIM-HL VKF
ERDÉLYI Ernő: Győr veszélyeztetettsége. Győr, 1936, Győri Hírlap. 36 p.

Halász János: Légitámadás és légvédelem. Miskolc, 1936, Miskolci Könyomda. $131 \mathrm{p}$.

HÉJJAS Iván: Légijog. I. köt. Kecskemét, 1934, Első Kecskeméti Hírlapkiadó- és Nyomda Rt. 144 p.

KAISER Ferenc: A Magyar Királyi Csendörség története a két világháború között. Pécs, 2002, Pro Pannónia Kiadó Alapítvány. 175 p. HU-ISBN 963907982 0. /Pannónia Könyvek/ HU-ISSN 0237-4277.

- M. Szabó Miklós: A Magyar Királyi Honvéd Légierő 1938-1945. Budapest, 1999, Zrínyi Kiadó. 314.p. HU-ISBN: 963327334 X.

SzentNÉMEDy Ferenc: A repülés. Budapest, 1933, Magyar Szemle Társaság. $79 \mathrm{p}$.

FABINI Tihamér: A légvédelem jelentősége. Magyar Katonai Szemle. VI.évf. (1936) 11.sz. 137-143.p.

FINTOR Sándor: A korszerü légvédelmi figyelő szolgálatról. Magyar Katonai Szemle, IV.évf. (1934) 12.sz. 122-126.p.

Moys Péter: A légtérfelhasználás és légi felségjog gyakorlásának jogi vonatkozásai (hazánk euró-atlanti integrációjának tükrében). Magyar Szárnyak, XXVII.évf. (1997) 27.sz. 169-177.p. HU-ISSN 1416-6577.

PARÁDI József: A Magyar Királyi Csendőrség szervezete. Rendvédelemtörténeti Füzetek (Acta Historiae Praesidii Ordinis), XXI. évf. (2011) 24.sz. 80-90.p. HU-ISSN 1216-6774. A tanulmány korábbi változata 2009. december 3. Budapesten hangzott el, a Szemere Bertalan Magyar Rendvédelem-történeti Tudományos Társaság által szervezett rendvédelem-történeti tudományos konferenciasorozatnak „Csendörség Ausztria-Magyarországon, illetve Ausztriában és Magyarországon 1849-2005” című XXIV. konferenciáján. A publikált tanulmány az előadás javított, bővített és átdolgozott változata.

PARÁDI József: Nemzeti határörizetünk polgári szakasza. Rendvédelemtörténeti Füzetek (Acta Historiae Praesidii Ordinis), XXIII. évf. (2013) 2728-29-30.sz. 141-154.p. HU-ISSN 1216-6774. A tanulmány korábbi változata 2011. november 11-én, Budapesten hangzott el a Szemere Bertalan Magyar Rendvédelem-történeti Tudományos Társaság által szervezett rendvédelem-történeti tudományos konferenciasorozatnak a „Militarizmus és demilitarizmus a XIX-XX. századi magyar rendvédelemben" címü XXVI. konferenciáján. A publikált tanulmány az előadás javított, bővített és átdolgozott változata.

RÉCZEY Ferenc: Nemzetközi légi erök. Magyar Katonai Szemle, V.évf. (1935) 6.sz. 110-116.p.

SiLlay Aladár: Katonai légi járművek nemzetközi jogi helyzete. Magyar Katonai Szemle, I. évf. (1931) 12. sz. 121-132.p.

Tо́тн Elemér: A légvédelmi figyelő és jelentő szolgálat befolyása a légi hadmüveletekre. Magyar Katonai Szemle, VI. évf. (1936) 2. sz. 101-108.p.

- Berkovics Gábor: A figyelö- és jelentőszolgálat története Magyarországon 1917-1945. Releváns külső és belsö katonai környezete a két világháború között. PhD értekezés. Budapest, 2000, ZMNE. 133 p.

- ALKÉr Kálmán - AMBrózy Gyula (szerk.): A Magyar Békeszerződés és a becikkelyezö törvény szövege és magyarázata. Budapest, 1921, „Ordo” Törvény- és Rendelettár. 333 p. /Az Ordo törvénytára, 4./

— Hadtörténeti Intézet és Múzeum Hadtörténelmi Levéltára, Honvédelmi Minisztérium.

Hadtörténeti Intézet és Múzeum Hadtörténelmi Levéltára, Personaliák.

- Hadtörténeti Intézet és Múzeum Hadtörténelmi Levéltára, Tanulmánygyüjtemény.

Hadtörténeti Intézet és Múzeum Hadtörténelmi Levéltára, Honvéd Vezérkar Főnöke. 
MNL-MOL K-149 BM Eln.res.

MNL-MOL K-149 BM Eln.ált.

\section{JOGSZABÁLYOK}

10 270/1922. (XII. 14.) ME.r.

1630/1924. (II. 22.) ME.r.

45 332/1924. (II. 25.) KEM.r.

115 000/1933. (XII. 22.) KEM.r.
Magyar Nemzeti Levéltár Magyar Országos Levéltára, Belügyminisztérium Elnöki rezervált iratok.

Magyar Nemzeti Levéltár Magyar Országos Levéltára, Belügyminisztérium Elnöki általános iratok.

10 270/1922. (XII. 14.) ME.r. a légi közlekedésröl. Magyarországi rendeletek tára. LVI.évf. (1923) 1.sz. 192-203.p.

1630/1924. (II. 22.) ME.r. a légi közlekedésről szóló rendelet módosításáról és kiegészítéséröl.

Magyarországi rendeletek tára, LVIII.évf. (1925) 1.sz. 30-32.p.

- $\quad 45$ 332/1924. (II. 25.) KEM.r. a külföldi légi járómüvek közlekedéséről. Magyarországi rendeletek tára, LVIII.évf. (1925) 1.sz. 697-700.p. röl.

Magyarországi rendeletek tára, LXVII.évf. (1934) 3069-3083.p.

Mellékletek jegyzéke:

I.sz. melléklet

Légirendészeti és légvédelmi parancsnokságok 1924.

II.sz. melléklet

Idegen repülögépek számára kijelölt repülöterek és légikapuk 1924.

IIII.sz. melléklet

Tiltott repülési zónák 1939.

IV.sz. melléklet

Országos légvédelmi rendszer 1936.

V.sz. melléklet

A Magyar Királyság ,, légi csendörsége”.

VI.sz. melléklet

A Magyar Királyság katonai légvédelmi figyelö- és jelentö szolgálata.

Légirendészeti és légvédelmi parancsnokságok 1924.

I.sz. melléklet

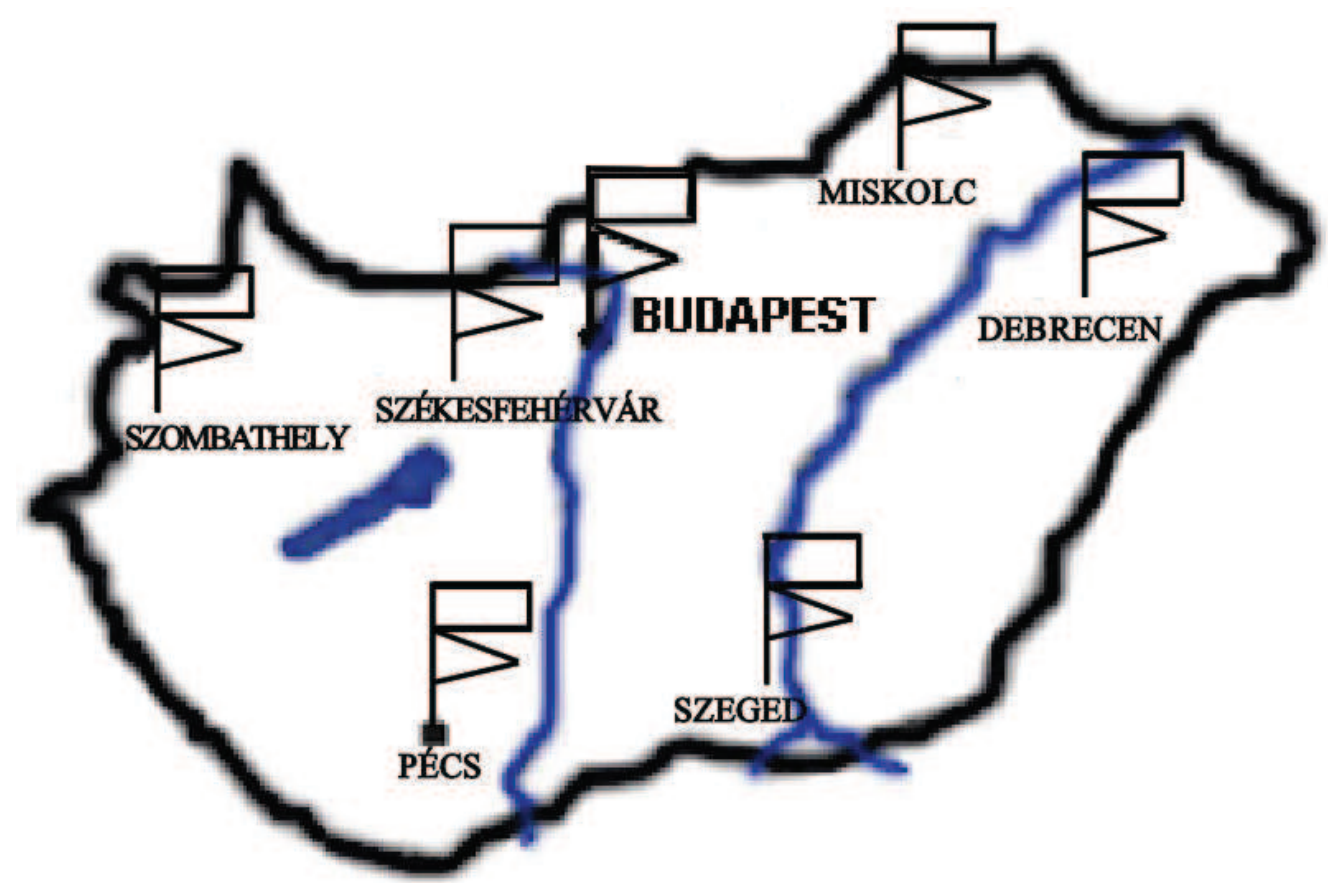

$P$

Reptérgondnokságok csendőr különítményei

Légvédelmi

Kerületi Központ

Forrás ! HIM-HL VKF Eln. 1. 6117/1924. ; HL TGY 2787. II. rész 19.p. ； HIM-HL TGY 2974. I. rész 30.p. 
Idegen repülögépek számára kijelölt repülöterek és légikapuk 1924.

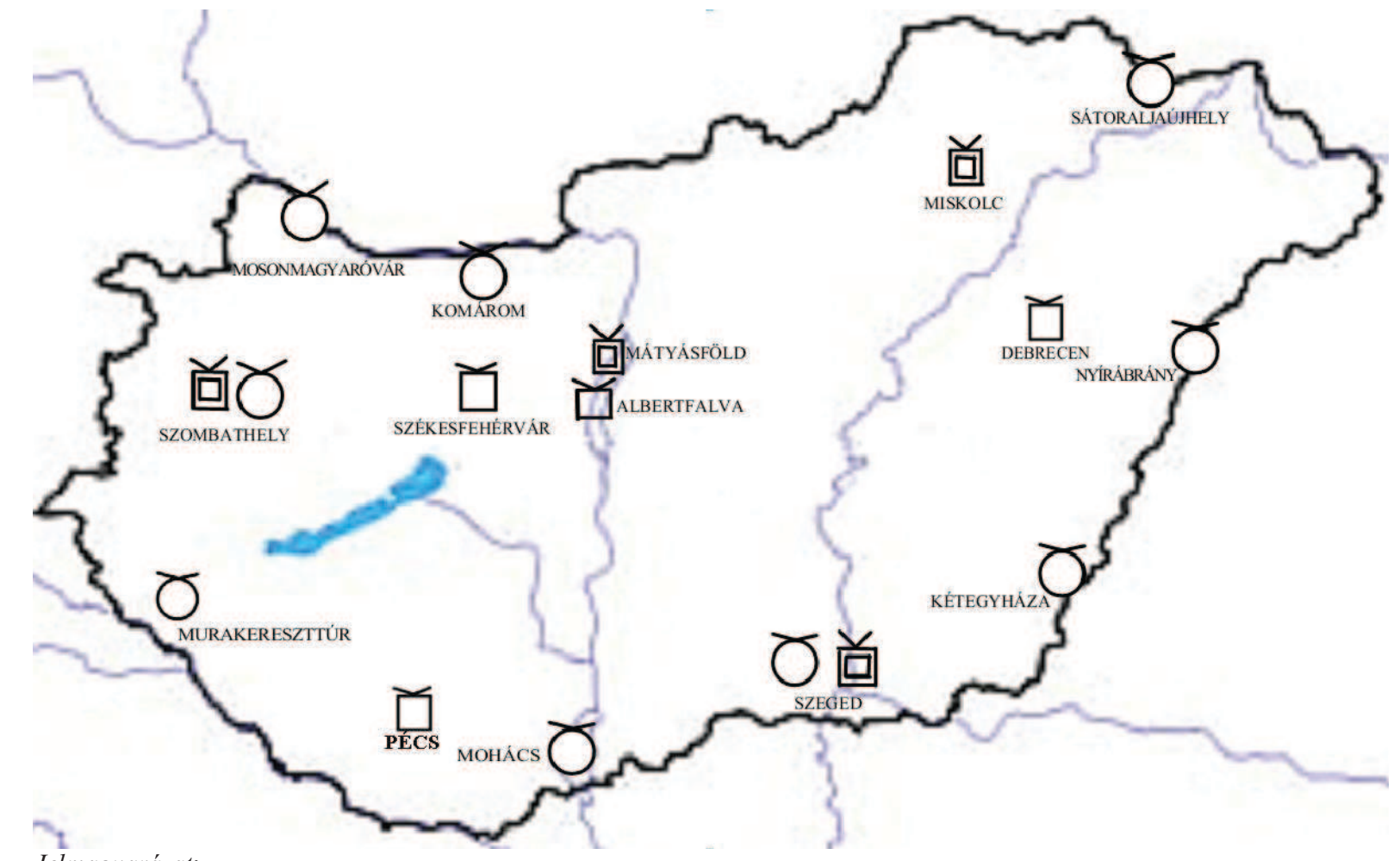

Jelmagyarázat:

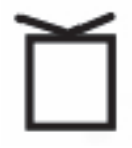

Állandó repülőtér

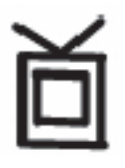

Tartalék repülőtér

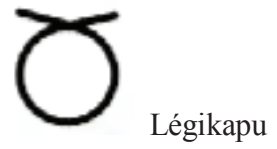

Forrás ! MOL K 150. BM Eln. 1924-V-7945. ;

Tiltott repülési zónák 1939.

III.sz. melléklet

\section{Jelmagyarázat:}

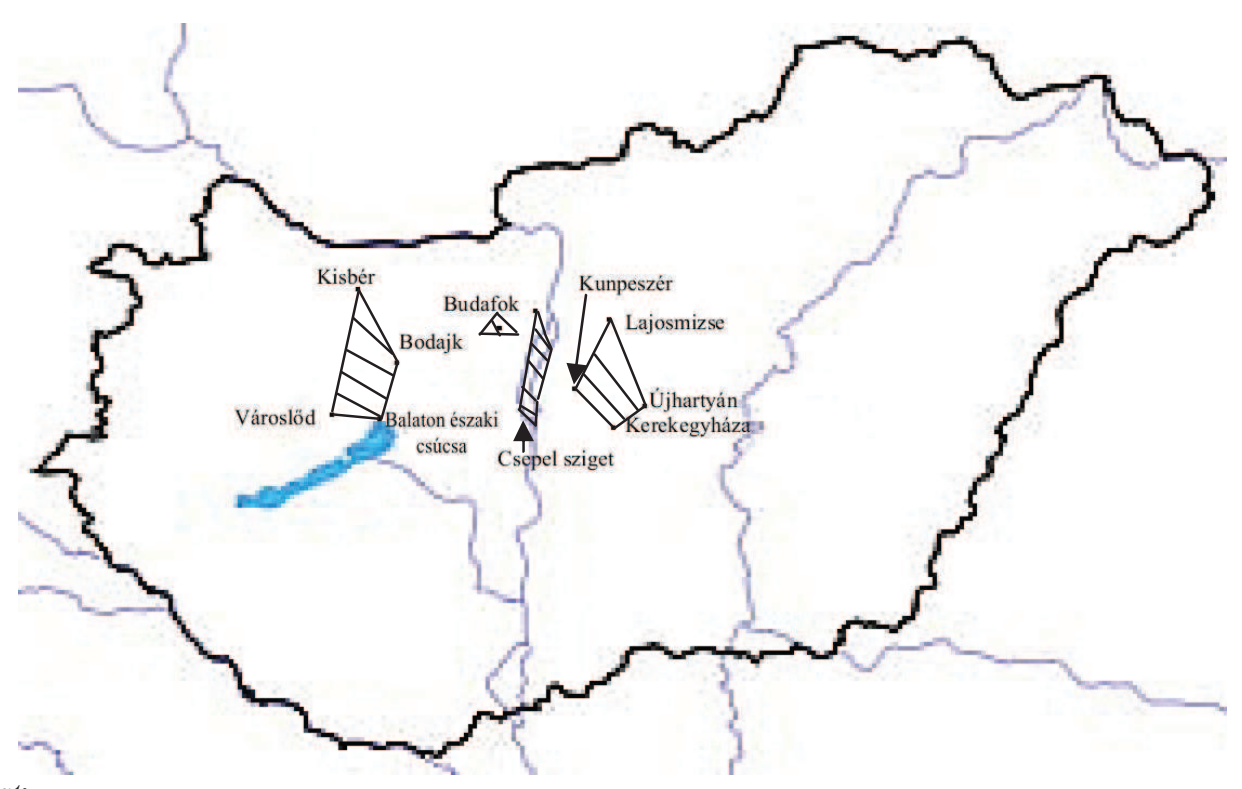

Forrás ! HIM-HL Eln. I. 106 083/1930. ; HIM-HL VKF op.cit. Eln. 1. 1080/1931. 


\section{Országos légvédelmi rendszer 1936.}

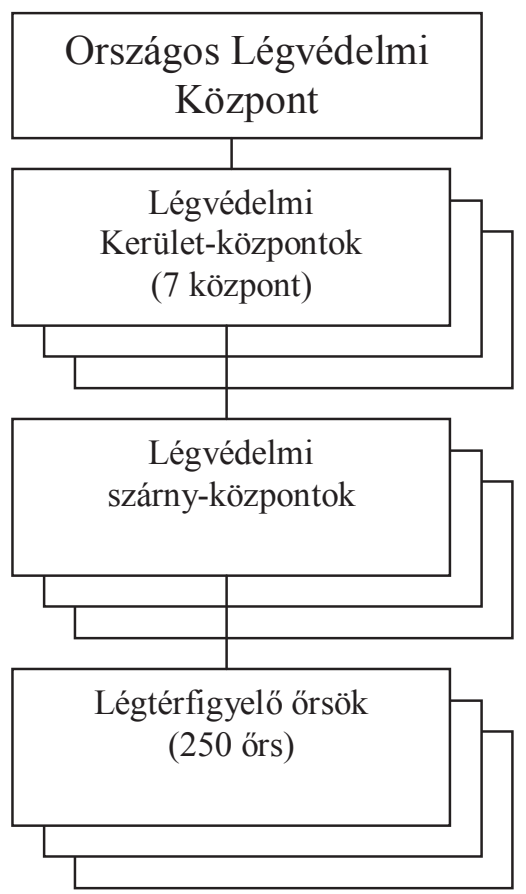

Az országos légvédelmi rendszer a Magyar Királyi Honvédség szervezetében müködött.

Forrás ! HIM-HL HM op.cit. Elns. 14 608/1936

A Magyar Királyság „légi csendőrsége”.

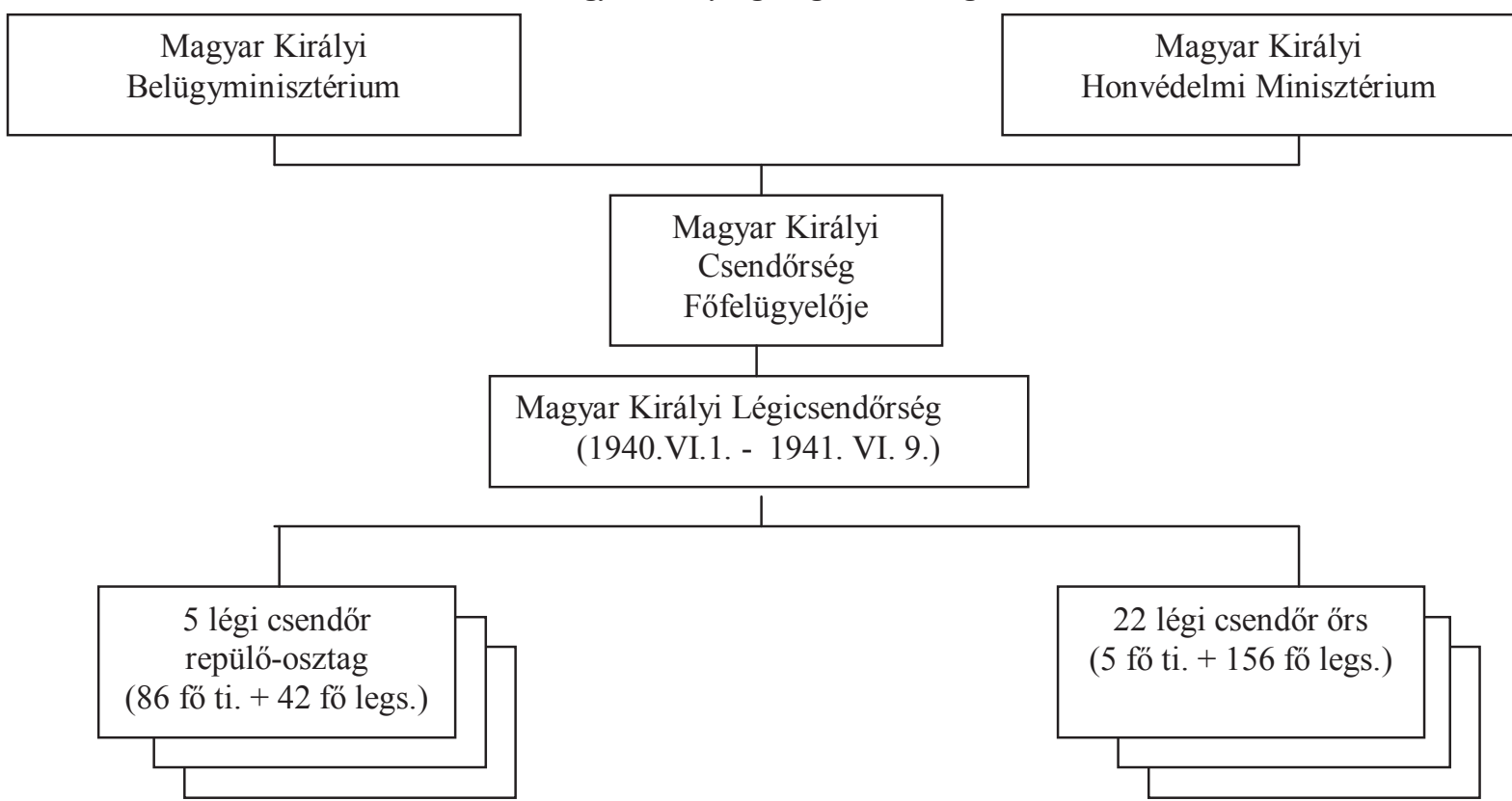

Magyarország hadbalépése után a polgári légi ellenőrző szolgálat megszünt, feladatait a katonai légvédelmi figyelő - és jelentőszolgálat vette át.

Forrás ! HIM-HL HM Eln. 1. 4611/1939., 4672/1939. ; HIM-HL HM Eln. 1. 3655/1940. ; HIM-HL TGY. 2787. V. rész 25.p. 
A Magyar Királyság katonai légvédelmi figyelö- és jelentő szolgálata.

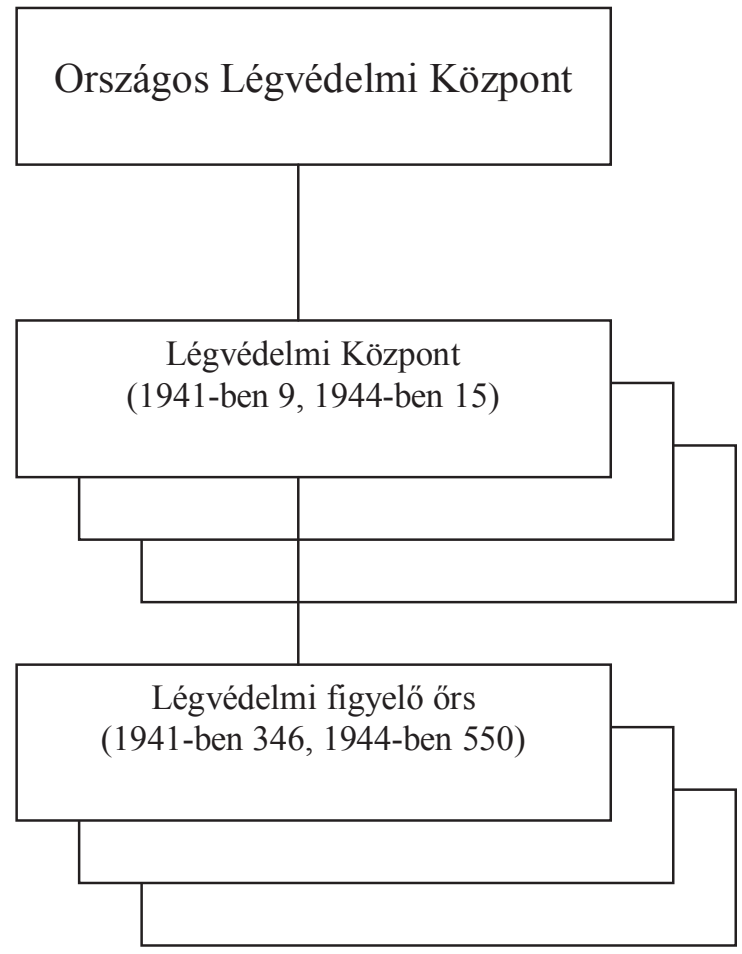

Forrás ! HIM-HL VKF Eln. 1. 5122/1941., 6948/1941. ; HIM-HL VKF Eln. Om. 26/1943. 